\title{
ERRATUM
}

\section{Erratum to: Active vibration control of a dynamical system via negative linear velocity feedback}

\section{H. S. Bauomy}

Published online: 29 March 2014

(C) Springer Science+Business Media Dordrecht 2014

\section{Erratum to: Nonlinear Dyn DOI 10.1007/s11071-014-1306-4}

3 Unfortunately, the following errors remain in the original publication:

In Table 1 the second column header should read 'Without controller' and the third one 'With controller' (instead of the other way around).
The online version of the original article can be found under doi:10.1007/s11071-014-1306-4.

\section{H. S. Bauomy $(\varangle)$}

Department of Mathematics, Faculty of Science,

Zagazig University, Zagazig 44519, Egypt

e-mail: hany_samih@yahoo.com

\section{H. S. Bauomy}

Department of Mathematics, College of Arts and Science in Wadi Addawasir, Salman Bin Abdulaziz University,

P.O. Box 54, Wadi Addawasir 11991, Saudi Arabia
In the first paragraph of Sect. 4.2, 'roll mode $\omega_{1}$ ' 8 and 'pitch mode $\omega_{2}$ ' should read 'first mode $\omega_{1}$ ' and 9 'second mode $\omega_{2}$ ', resp. 